\title{
Palkokasveista valkuaista ja sulavuutta kokoviljaseoksiin
}

\author{
Arja Nykänen ${ }^{1)}$, Marketta Rinne ${ }^{2)}$ ja Lauri Jauhiainen ${ }^{3)}$ \\ 1) MTT Kasvintuotannon tutkimus,Lönnrotinkatu 3,50100Mikkeli,arja.nykanen@mtt.fi \\ 2)MTT Kotieläintuotannon tutkimus,31600 Jokioinen, marketta.rinne@mtt.fi \\ 3) MTT Kasvintuotannon tutkimus,31600 Jokioinen, lauri.jauhiainen@mtt.fi
}

\section{Tiivistelmä}

Kotovaraisen eli tiloilla itse kasvatetun rehuvalkuaisen tuottaminen on alkanut kiinnostaa viime aikoina yhä enemmän viljelijöitä ja kotieläintuottajia. Kaupallisen valkuaisrehun hinnan vaihtelut ja laatu- ja saatavuusongelmat tuovat epävarmuutta, lisäkuluja ja riskejä kotieläinten ruokinnan hallintaan ja suunnitteluun. Nautakarjatiloilla on joissain tapauksissa luovuttu puitavan viljan viljelystä. Viljelykierrossa mukana oleva vilja korjataan silloin kokoviljasäilörehuksi ja tämä suuntaus tulee jatkossa todennäköisesti lisääntymään. Kokoviljasäilörehun alhainen valkuaispitoisuus ja sulavuus (D-arvo) voivat olla ongelmia erityisesti lypsylehmien ruokinnassa. Yksivuotiset palkokasvit kuten herneet ja virnat viljojen seassa tuovat apua tähän ongelmaan. Samalla pystytään vähentämään ostovalkuaisrehun tarvetta.

MTT:1lä tutkittiin vuosina 2005-2007 erilaisia palkokasvien ja viljojen seoksia kokoviljasäilörehun raaka-aineeksi. Kenttäkokeissa testattiin viljoista kevätvehnää, kauraa, ohraa sekä kevät- ja syysruista ja palkokasveista rehu- ja vihantarehuhernettä sekä rehu- että ruisvirnaa. Kokeet toteutettiin osaruutukokeina, joissa pääruutuina olivat seokset ja osaruutuina oli kolme eri sadonkorjuuajankohtaa. Sadoista määritettiin kokonaiskuiva-ainesato, kasvilajikoostumus sekä kasvilajeittain raakavalkuaisen (RV) pitoisuus ja orgaanisen aineen sulavuus (OAS). Satotulokset on raportoitu rinnakkaisartikkelissa (Nykänen \& Jauhiainen, Maataloustieteen Päivät 2010).

Lypsylehmille syötettävän karkearehun OAS:n tulisi olla noin $720-740 \mathrm{~g} \mathrm{~kg}^{-1}$. Tällaista rehua saatiin joistakin seoksista, joissa oli hernettä ja ohraa. RV-pitoisuus puolestaan oli suositellun $140 \mathrm{~g}$ $\mathrm{kg}^{-1}$ :n suuruinen tai korkeampi seoksissa, joissa oli mukana virnaa. Kasvikohtaisissa analyyseissä havaittiinkin, että palkokasvien sulavuus ja valkuaispitoisuus on selkeästi korkeampi kuin viljojen. Kasvukauden edetessä niiden pitoisuudet myös mieluummin nousevat kuin laskevat, joten ne lisäävät myös joustoa korjuuaikaan puhtaisiin viljoihin verrattuna.

Siemenseoksia suunniteltaessa täytyy ottaa huomioon kasvien ominaisuudet. Kasvilajivalinta täytyy tehdä myös sen mukaan, tarvitaanko tilalla hyvin sulavaa ja valkuaispitoista rehua lypsylehmille ja lihanaudoille vai onko tilalla hiehoja ja emolehmiä, jotka tarvitsevat yleensä vähemmän energiaa ja valkuaista.

Asiasanat: D-arvo, herne, kaura, ohra, ruis, virna, vehnä, orgaanisen aineen sulavuus raakavalkuainen 


\section{Johdanto}

Nautakarjatiloilla nurmet säilörehuksi tai heinäksi korjattuna tai laidunruohona ovat pääasiallinen karkearehu ruokinnassa..Nautakarjan ruokinta perustuu lähes poikkeuksetta omalla tilalla tuotettuihin nurmirehuihin. Yleensä tuotetaan myös rehuviljaa. Rehuviljan viljelystä on mielekästä luopua, jos karjakoon kasvaessa koko peltopinta-ala tarvitaan karkearehujen tuotantoon. Karjanlannan levitys voi olla ongelmallista jatkuvassa nurmiviljelyssä. Myös nurmien uusimiseen viljat ovat sopivia suojakasveja. Viljan korjaaminen kokoviljasäilörehuksi sopii hyvin tällaisen tilan viljelykiertoon ja sen käyttö nautakarjan rehuna on lisääntymässä. Kokoviljasäilörehu tuottaa yhdellä sadonkorjuukerralla tyypillisesti kohtuullisen suuren sadon. Kokoviljasäilörehu ei sovellu käytettäväksi ainoana karkearehuna lypsylehmille eli se sopii parhaiten tiloille, joilla käytetään seosrehuruokintaa.

Typen hyväksikäyttö maidontuotannossa riippuu pääasiassa syötetyn rehuannoksen raakavalkuaisen (RV) pitoisuudesta (Huhtanen ym. 2008). Koska kokoviljasäilörehun RV -pitoisuus on tyypillisesti pienempi kuin muiden karkearehujen, on sen käytön havaittu parantavan lypsylehmien rehun typen hyväksikäyttöä.

Lehmien vapaaehtoinen karkearehujen syönti on lisääntynyt, kun osa nurmisäilörehusta on korvattu kokoviljasäilörehulla (Huhtanen ym. 2007, Rinne ym. 2008a). Lehmät ovat syöntiä lisäämällä pystyneet kompensoimaan kokoviljasäilörehun pienempää energiapitoisuutta niin, että ne ovat pystyneet ylläpitämään maitotuotoksen (Thornton \& Minson 1973, Phipps ym. 1995, Ahvenjärvi ym. 2006).

Palkokasvirehut lisäävät tyypillisesti eläinten rehun syöntiä ja niiden sulatus- ja virtausnopeudet pötsissä ovat nopeita (Waghorn ym. 1989, Sutton ym., 1997, Mustafa ym. 2000). Tutkimusten mukaan märehtijät syövät myös enemmän useista kuin yhdestä kasvilajista tehtyjä rehuja (Sutton ym. 1997, Huhtanen ym. 2007, Rinne ym. 2008a). On myös huomattu, että eläinten tuotos paranee, kun niille syötetään rehuja, jotka sisältävät sekä runsaasti energiaa että valkuaista sisältäviä kasveja (Adesogan ym. 2000, Anil ym. 2000, Salawu ym. 2000).

Alhaisen sulavuutensa ja valkuaispitoisuutensa vuoksi pelkästään viljoista valmistettua kokoviljasäilörehua ei ole pidetty korkeatuottoisten lehmien ja lihanautojen rehuna. Yksivuotiset palkokasvit kuten herneet ja virnat viljojen seassa voisivat tuoda apua tähän ongelmaan. Samalla pystyttäisiin vähentämään ostovalkuaisrehun tarvetta. Tämä voi tuoda taloudellisia etuja ja lisää niin yksittäisen karjatilan kuin koko Suomen valkuaisomavaraisuutta. Lisäksi se vähentää riippuvuutta kaupallisista valkuaisrehuista, joiden hintavaihtelut ja laatu- ja saatavuusongelmat erityisesti luomutuotannossa voivat vaikeuttaa kotieläintuotantoa.

Karkearehun laadun varmistamiseksi sen oikea korjuuaika on tärkeä tuotannon vaihe, sillä kasvien ominaisuudet muuttuvat kasvuajan ja tuleentumisen edetessä (Åman \& Graham 1987, Mustafa \& Sequin 2004). Kasvuaika voidaan ilmasta kasvupäivinä tai tehoisana lämpösummana (TLS), joka on $+5{ }^{\circ} \mathrm{C}$ ylittävien lämpöasteiden kumulatiivinen määrä. Nykyisin on yhä enemmän alettu käyttää TLS:aa, koska se kuvaa hyvin kasvien kehityksen edistymistä.

Tämän tutkimuksen tavoitteena on selvittää erilaisten palkokasveja ja viljoja sisältävien kokoviljasäilörehuksi korjattavien seosten ruokinnallista laatua eli RV-pitoisuutta ja orgaanisen aineen sulavuutta (OAS). Lisäksi näitä ominaisuuksia seurataan kasvilajeittain kasvukauden edetessä suhteuttaen kehitys TLSaan. Tulokset hyödyttävät sekä luonnonmukaisesti että tavanomaisesti viljeleviä maidon ja lihan tuottajia. Rinnakkaisartikkelissa käsitellään kokoviljasäilörehujen sadon tuottoa (Nykänen ym. 2010). Tästä aineistosta on julkaistu myös englanninkielinen artikkeli (Nykänen ym. 2009)

\footnotetext{
Aineisto ja menetelmät

Vuosina 2005-2007 tutkittiin MTT:n Juvan tutkimusasemalla erilaisia palkokasvien ja viljojen seoksia kokoviljasäilörehun raaka-aineeksi. Kokeet viljeltiin luonnonmukaisin menetelmin käyttäen lannoitteeksi $30000 \mathrm{~kg} \mathrm{ha}^{-1}$ karjanlantaa. Koemallina kokeissa oli neljän kerranteen osaruutukoe, jossa pääruutuna oli kylvöseos ja osaruutuina oli kolme eri sadonkorjuuajankohtaa. Käytetty tilastollinen malli oli koeasetelmaan perustuva sekamalli (mixed model), joka ottaa huomioon vuosittaisen vaihtelun. Täten tulokset ovat vertailukelpoisia, vaikka kaikkia seoksia ei viljelty joka vuosi. Mallissa ns. kiinteinä tekijöinä olivat niittoaika, seos ja niiden yhdysvaikutus. Lisäksi mallissa oli ns. satunnaistekijöinä (random effects) vuosi, lohko vuoden sisällä sekä yhdysvaikutukset vuosi*seos,
} 
lohko*vuosi*seos, vuosi*niittoaika ja vuosi*seos*niittoaika. Analyysit toteutettiin SAS/MIXED ohjelmalla (SAS 2004).

Kokeet kylvettiin touko-kesäkuun vaihteessa ja korjattiin heinäkuun puolivälistä elokuun puoliväliin vaihdellen eri vuosina kuitenkin niin, että eri korjuukertojen väliin jäi noin 10 päivää. Näin ollen kasvupäivien määrä vaihteli 48 ja 85 välillä ja tehoisan lämpösumman määrä vastaavina kasvuaikoina oli 450-920 astetta (ks. Nykänen \& Jauhiainen 2010, Taulukko 2).

Kenttäkokeissa testattiin viljoista kevätvehnää (Triticum aestivum L., cv. 'Amaretto'), kauraa (Avena sativa L., cv. 'Roope'), ohraa (Hordeum vulgare L., cv. 'Polartop') sekä kevät- ja syysruista (Secale cereale L. cv. 'Juuso' ja cv. 'Riihi') ja palkokasveista rehu- ja ruisvirnaa (Vicia sativa L., cv. 'Ebena', Vicia villosa Rot., cv. 'Hungavillosa') sekä rehu- ja vihantarehuhernettä (Pisum sativum L.). Hernelajikkeista mukana olivat 'Timo', joka edustaa reheväkasvuisia vihantarehuherneitä, 'Nitouche' edustaen lyhytkortisia siementuotantoon jalostettuja rehuherneitä ja 'Algarve', joka sijoittuu näiden väliin. Siemenseoksissa käytettiin keskimäärin $120-180 \mathrm{~kg} \mathrm{ha}^{-1}$ viljoja sekä $15-80 \mathrm{~kg} \mathrm{ha}^{-1}$ hernettä ja/tai 20-40 kg ha' virnoja. Lisäksi osaan kylvettiin $10 \mathrm{~kg} \mathrm{ha}^{-1}$ italianraiheinää (Lolium multiflorum Lam., cv. Meroa). Siemenseokset on selitetty tarkemmin rinnakkaisartikkelissa (Nykänen \& Jauhiainen 2010, Taulukko 1).

Sadoista määritettiin kokonaiskuiva-ainesadon ja kasvilajikoostumuksen lisäksi kasvilajeittain RV-pitoisuus ja OAS. Kasvien kokonaistyppipitoisuus analysoitiin Kjeldahl-menetelmällä (AOAC method 984.13) ja tulos kerrottiin 6,25:1lä, jotta lopputulokseksi saatiin RV-pitoisuus. In vitro orgaanisen aineen sulavuus määritettiin pepsiini-sellulaasi-menetelmän muunnoksella (Nousiainen ym. 2003). Tulokset laskettiin kasvikohtaisilla korjausyhtälöillä, jotta in vitro -tulokset saatiin muunnettua lampaan ylläpitomäärityksiä vastaaviksi (Huhtanen ym. 2006, Rinne ym. 2008b). Viljoille käytettiin kokoviljayhtälöä ja herneille ja virnoille puna-apilayhtälöä. Satotulokset on raportoitu rinnakkaisartikkelissa (Nykänen \& Jauhiainen 2010).

\section{Tulokset ja tulosten tarkastelu}

Lypsylehmille syötettävän karkearehun OAS:n tulisi olla 720-740 g kg-1 (D -arvo 670-690 g kg-1 KA). Tällaista rehua ei saatu käytännössä mistään testatuista seoksista (Taulukko 1). Seoksilla, joissa oli vihantarehuhernettä ja ohraa (OhraHerne), päästiin joissakin tapauksissa näihin arvoihin kuin myös kauraa ja virnaa (KauraVirna) sisältävien seosten ensimmäisessä korjuussa (tuloksia ei esitetty). Alhaisin sulavuus oli kevätruista sisältäneessä seoksessa (VehnäVirnaRuis ${ }^{\text {Juuso }}$ ).

Valkuaispitoisuus puolestaan oli suositellun $140 \mathrm{~g} \mathrm{~kg}^{-1}: \mathrm{n}$ suuruinen tai yli seoksissa, joissa oli mukana virnaa $\left(\operatorname{Seos}^{\text {Timo }}{ }^{\text {, Seos }}{ }^{\text {Algarve }}\right.$, VehnäVirnaRuis ${ }^{\text {Rihi }}$, KauraVirna; Taulukko 1). Yksittäisten rehujen tavoitearvojen käyttö on hieman ongelmallista, koska kotieläinten rehuannokset koostetaan tyypillisesti useista eri komponenteista ja tavoitearvot tarkoittavat koko rehuannoksen koostumusta. Yksittäisen rehuannoksen tavoitearvosta huomattavastikin poikkeava koostumus voi olla jopa etu, jos se tasapainottaa muiden komponenttien toiseen suuntaan poikkeavia arvoja. Esimerkiksi kokoviljasäilörehun RV -pitoisuustavoitteiden asettaminen riippuu siitä, kuinka paljon RV:tä sen kanssa syötettävä nurmisäilörehu sisältää.

Taulukko 1. Kokoviljasäilörehuseosten orgaanisen aineen sulavuudet (OAS, $\left.\mathrm{g} \mathrm{kg}^{-1}\right)$ ja raakavalkuaispitoisuudet (RV, g kg-1 KA) keskiarvoina yli kaikkien koevuosien ja sadonkorjuuajankohtien. Seosnimet viittaavat rinnakkaisartikkelin (Nykänen \& Jauhiainen 2010) taulukkoon 1. Arvot, joissa on eri kirjain yläindeksissä, eroavat toisistaan tilastollisesti $(\mathrm{P}<0.05)$. Suluissa keskiarvojen keskivirheet.

\begin{tabular}{|c|c|c|c|}
\hline Seos & $\mathbf{n}$ & $\begin{array}{l}\text { OAS } \\
\mathrm{g} \mathrm{kg}^{-1}\end{array}$ & $\begin{array}{l}\mathbf{R V} \\
\mathrm{g} \mathrm{kg}^{-1} \mathrm{KA}\end{array}$ \\
\hline $\operatorname{Seos}^{\text {Timo }}$ & 12 & $668^{\text {bc }}(29)$ & $158^{\mathrm{c}}(9)$ \\
\hline Seos ${ }^{\text {Algarve }}$ & 24 & $659^{\text {bc }}(24)$ & $148^{c} \quad(7)$ \\
\hline VehnäHerne $^{\text {Timo }}$ & 24 & $645^{\mathrm{abc}}(23)$ & $124^{\mathrm{ab}}(7)$ \\
\hline VehnäHerne ${ }^{\text {Nitouche }}$ & 24 & $630^{\mathrm{ab}} \quad(23)$ & $108^{\mathrm{a}} \quad(7)$ \\
\hline VehnäHerne ${ }^{\text {Algarve }}$ & 12 & $637^{\mathrm{abc}}(29)$ & $110^{\mathrm{a}}$ \\
\hline VehnäHerne Algarve2 & 12 & $661^{\text {bc }}(29)$ & $121^{\mathrm{ab}}(9)$ \\
\hline VehnäVirnaRuis Juuso & 24 & $591^{\mathrm{a}} \quad(24)$ & $107^{\mathrm{a}}(7)$ \\
\hline VehnäVirnaRuis ${ }^{\text {Riihi }}$ & 12 & $648^{\mathrm{abc}}(29)$ & $144^{\mathrm{c}}$ \\
\hline OhraHerne & 24 & $677^{\mathrm{bc}}$ & $117^{\mathrm{a}}$ \\
\hline KauraVirna & 24 & $658^{\text {bc }}(23)$ & $161^{\mathrm{c}}(7)$ \\
\hline
\end{tabular}




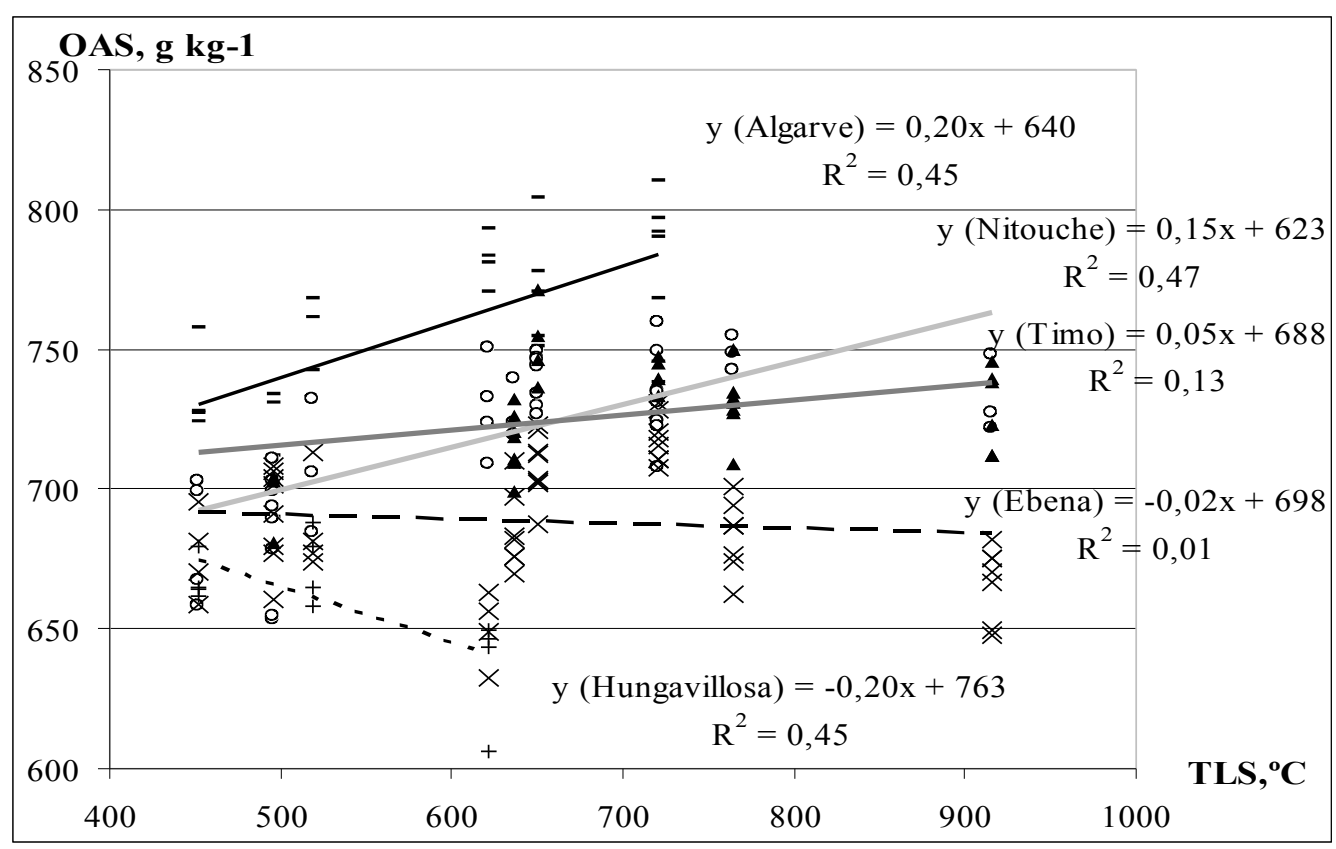

Kuva 1. Palkokasvien orgaanisen aineen sulavuuden (OAS, $\mathrm{g} \mathrm{kg}^{-1}$ ) kehittyminen tehoisan lämpösumman (TLS, $\left.{ }^{\circ} \mathrm{C}\right)$ suhteen. (Herneet Algarve $(-)$, Nitouche $(\circ)$, Timo $(\boldsymbol{\Delta})$ ja virnat Ebena $(\times)$, Hungavillosa $(+)$ )

Kasvikohtaisissa analyyseissä havaittiin, että korkeimmat OAS:t löytyivät herneiltä (690-810 $\left.\mathrm{g} \mathrm{kg}^{-1}\right)$ ja erityisesti 'Algarve' -herneeltä (Kuva 1.). Herneiden sulavuus myös nousi kasvukauden edetessä eli niiden korjuuajankohtaa voi pidentää sulavuuden kärsimättä. Tällöin voi siis odottaa, että kasvusto

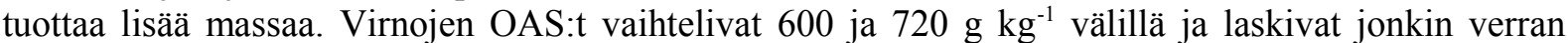
kasvukauden edetessä. Rehuvirnan sulavuudet olivat selkeästi korkeampia kuin ruisvirnan. Pursiainen ja Tuori (2008) mittasivat rehuherneelle ja rehuvirnalle keskimääräisiksi OAS -arvoiksi 751 ja $716 \mathrm{~g}$ $\mathrm{kg}^{-1}$, mitkä ovat samaa suuruusluokkaa meidän tulostemme kanssa.

Muissakin tutkimuksissa on havaittu, että esimerkiksi herneen ravitsemukselliset muutokset ovat hitaampia kuin kevätviljojen (Salawu ym. 2001, Borreani ym. 2007). Näiden arvojen muutokset selittyvät sekä kasvien eri osien kypsymisen aiheuttamilla muutoksilla että myös siemen/varsi suhteen muutoksilla. Esimerkiksi ohran ja kevätrukiin sulavuuden nousu selittynee sillä, että jyvien osuus koko biomassasta kasvoi jyvien alkaessa täyttyä.

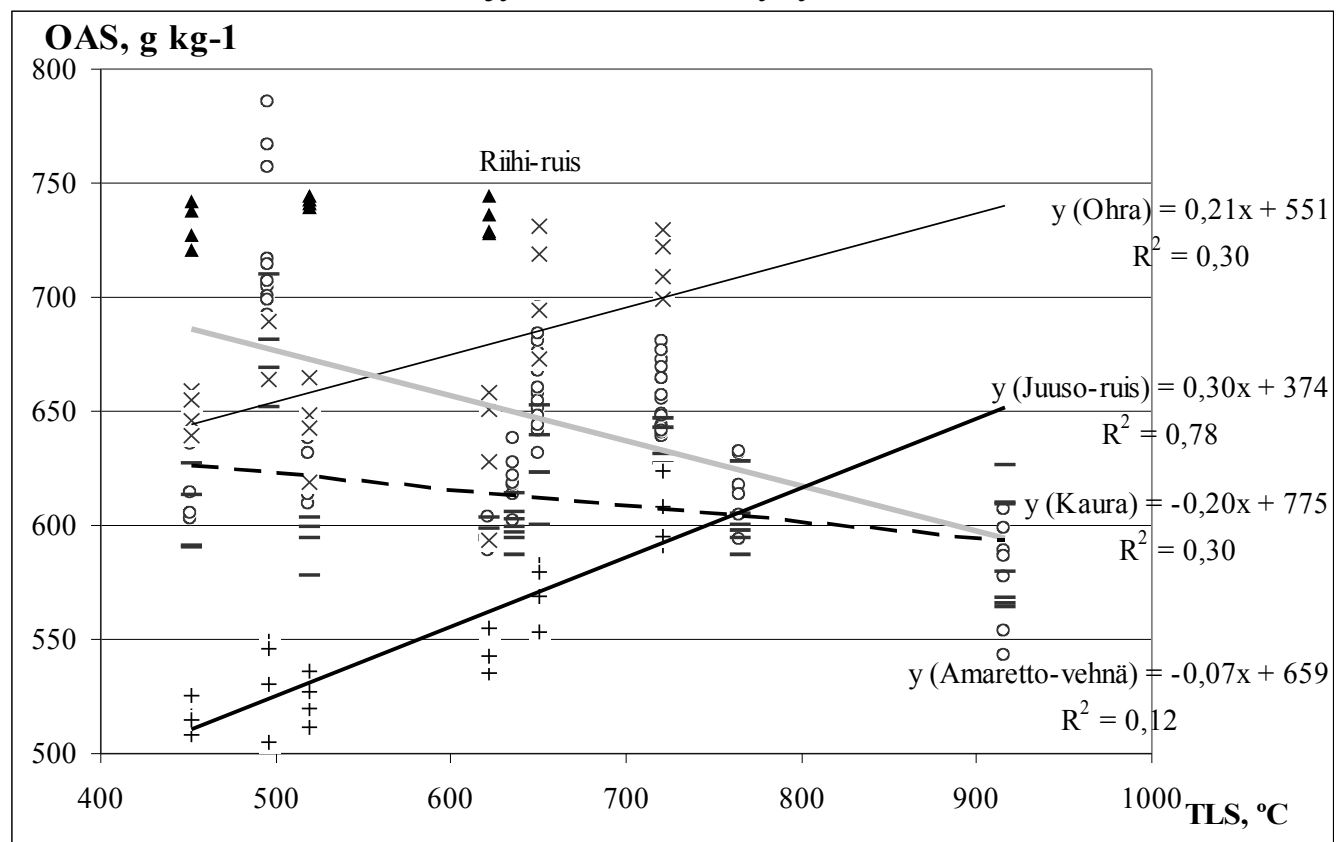

Kuva 2. Viljojen orgaanisen aineen sulavuuden $\left(\mathrm{OAS}, \mathrm{g} \mathrm{kg}^{-1}\right)$ kehittyminen tehoisan lämpösumman $\left(\mathrm{TLS},{ }^{\circ} \mathrm{C}\right)$ suhteen. (Vehnä $(-)$, Kaura (०), Riihi-ruis ( $\mathbf{\Delta})$, Ohra $(\times)$, Juuso-ruis $(+)$ ). 
Viljojen sulavuudet olivat pääasiassa tavoitearvojen alapuolella ja laskivat kasvukauden edetessä ohraa ja kevätruista lukuun ottamatta (Kuva 2). Kevätruis tuottaa niin paljon kuituista vartta, että sen sulavuudet jäävät joka tapauksessa alhaisiksi. Jos seoksessa on kauraa, pitäisi se korjata jo 50 päivän kuluttua kylvöstä (TLS $450-500{ }^{\circ} \mathrm{C}$ ), kun taas ohraa sisältävät seokset voivat kasvaa kolme viikkoa pidempään (TLS $650-700^{\circ} \mathrm{C}$ ). 'Anniina' -vehnän sulavuus laski jonkin verran hitaammin kuin 'Amaretto' -vehnän ollen 20 \%-yksikköä korkeampi $900{ }^{\circ} \mathrm{C}$ TLS:n kohdalla (tulosta ei ole esitetty Kuvassa 2) Keväällä kylvetyn Riihi -syysrukiin sulavuudet olivat korkeita (720-750 g kg ${ }^{-1}$ ).

Näiden kasvikohtaisten tulosten perusteella voi päätellä, että seosten alhaiset OAS:t selittyvät viljojen suurella osuudella korjatuissa sadoissa. Seoksissa käytettiin suhteellisen suuria viljamääriä (120-180 $\left.\mathrm{kg} \mathrm{ha}^{-1}\right)$ suhteessa palkokasvien määrään. Sulavuuden suhteen paras seos olisi ohraa ja hernettä sisältävä seos, jossa on runsaasti hernettä ja hiukan kauraa tukikasvina. Rondahl ym. (2006) käyttivät herne-kaura-seoksessa hernettä $200 \mathrm{~kg} \mathrm{ha}^{-1}$, jolloin OAS oli 740-820 g kg $\mathrm{g} \mathrm{kg}^{-1}$.

RV-pitoisuudet vaihtelivat kokeissamme suuresti ja korkeimmat pitoisuudet löydettiin virnoilta (160-280 $\mathrm{g} \mathrm{kg}^{-1} \mathrm{KA}$ ), joista erityisesti ruisvirnan RV-pitoisuudet olivat korkeita. Myös herneiden pitoisuudet olivat yli säilörehulle annetun tavoitearvon 120-140 g kg-1 KA (Kuva 3). Viljojen RVpitoisuudet puolestaan olivat käytännössä koko ajan alle suositusten (Kuva 4). Ainoa poikkeus oli keväällä kylvetty syysruis, jonka RV-pitoisuudet olivat $170-210 \mathrm{~g} \mathrm{~kg}^{-1} \mathrm{KA}$. 'Anniina' -vehnän RVpitoisuus oli ensimmäisessä korjuussa yhden prosenttiyksikön korkeampi kuin 'Amaretto' -vehnän, mutta viimeisessä sadonkorjuussa puolestaan 1,5 \%-yksikköä alhaisempi (tuloksia ei ole esitetty Kuvassa 4)

Pursiainen \& Tuori $(2006,2008)$ mittasivat omissa kokeissaan virnalta hiukan matalampia, herneeltä samantasoisia tai korkeampia ja ohralta korkeampia RV-arvoja kuin me. Tämä saattaa johtua lajike-eroista, mutta selityksenä voi olla myös se, että heidän kasvinsa oli viljelty tavanomaisin viljelymenetelmin, jolloin väkilannoitetypen käyttö voi alentaa typpeä sitovien kasvien typpipitoisuutta ja nostaa typpeä sitomattomien viljojen typpipitoisuutta.

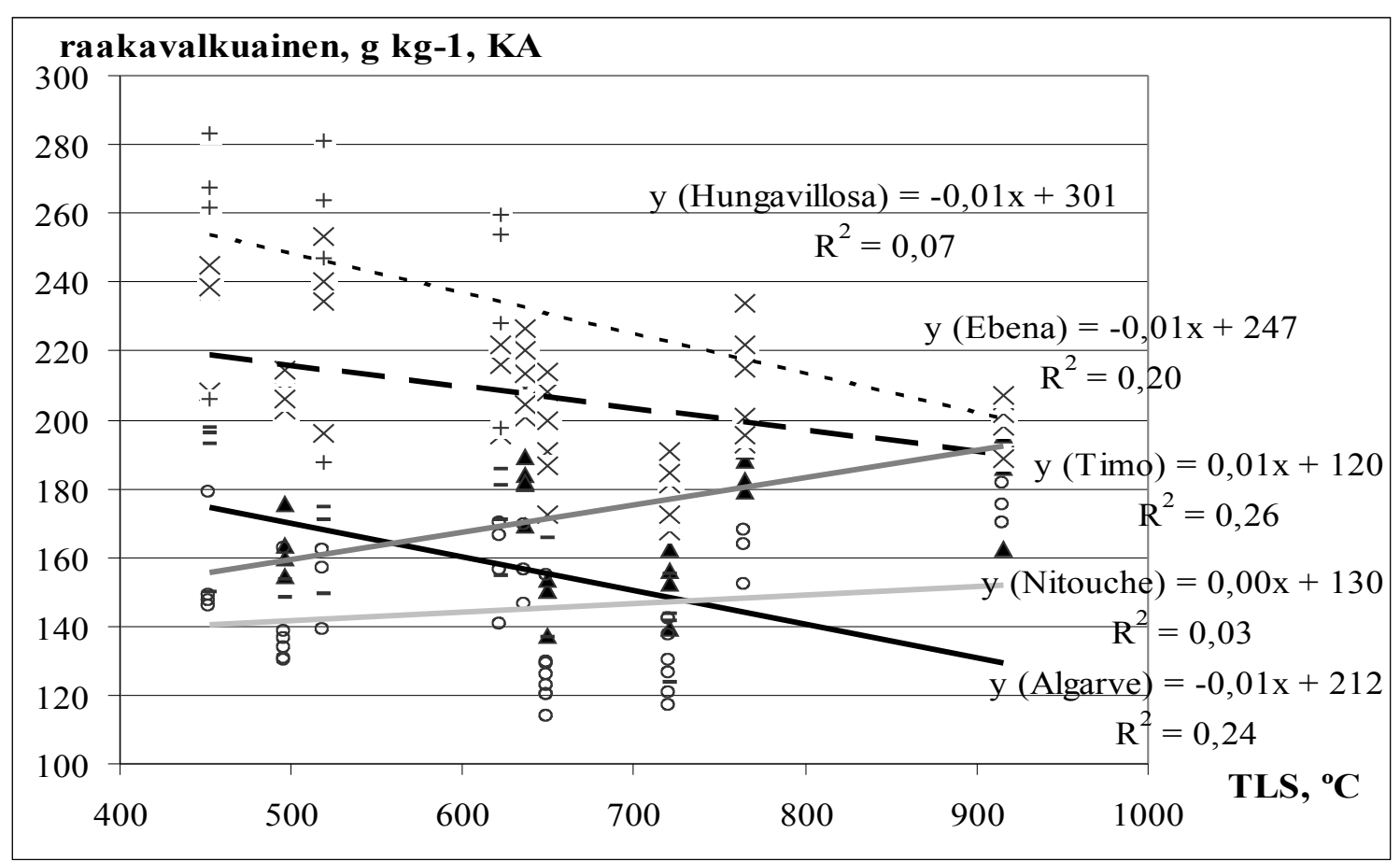

Kuva 3. Palkokasvien raakavalkuaispitoisuuden $\left(\mathrm{g} \mathrm{kg}^{-1} \mathrm{KA}\right)$ kehittyminen tehoisan lämpösumman $\left(\mathrm{TLS}\right.$, $\left.{ }^{\circ} \mathrm{C}\right)$ suhteen. ((Herneet Algarve $(-)$, Nitouche $(\circ)$, Timo ( $\mathbf{\Delta})$ ja virnat Ebena $(\times)$, Hungavillosa $(+))$. 


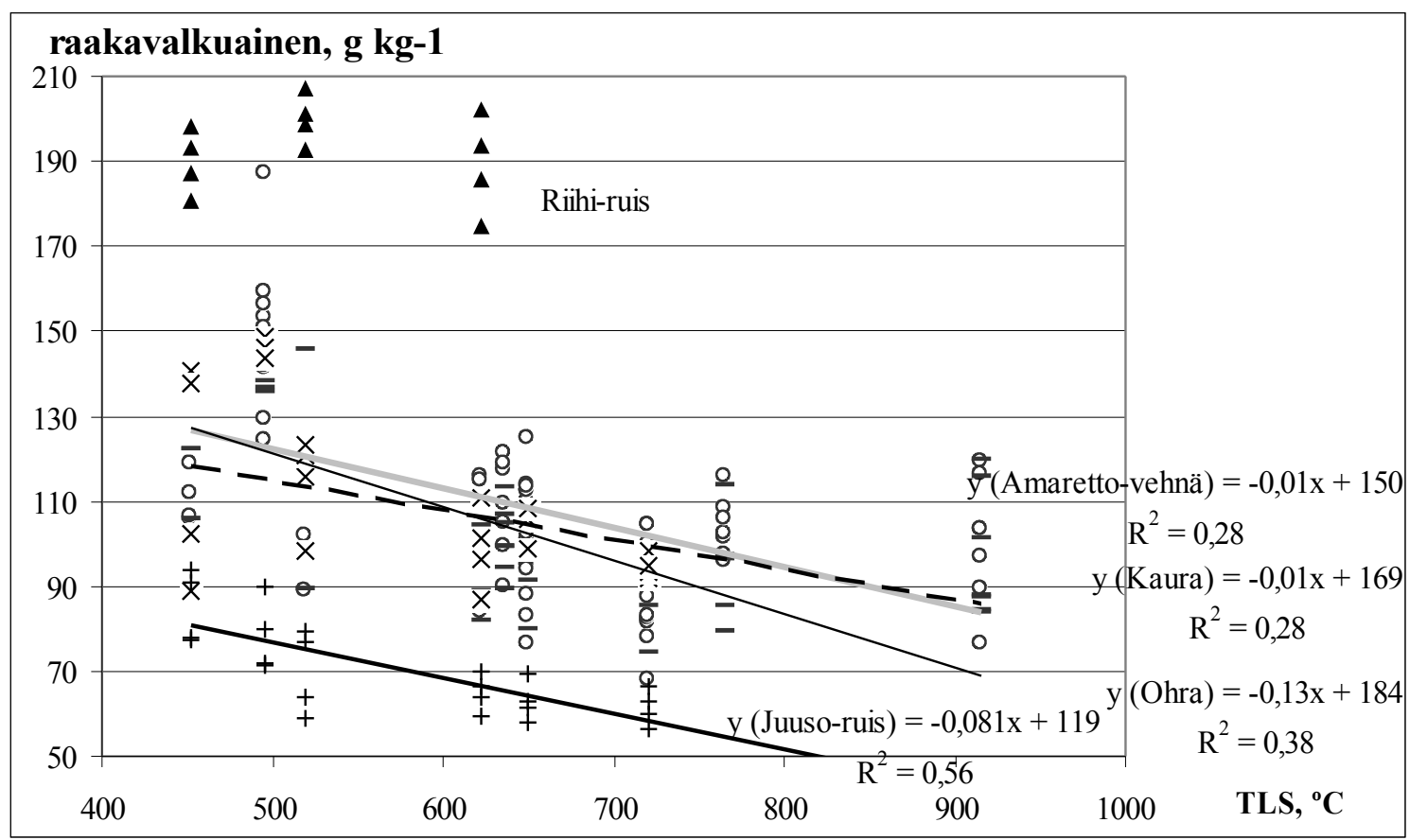

Kuva 4. Viljojen raakavalkuaispitoisuuden $\left(\mathrm{g} \mathrm{kg}^{-1} \mathrm{KA}\right)$ kehittyminen tehoisan lämpösumman $\left(\mathrm{TLS},{ }^{\circ} \mathrm{C}\right)$ suhteen. (Vehnä (-), Kaura (०), Riihi-ruis ( $\mathbf{\Delta})$, Ohra (×), Juuso-ruis $(+)$ ).

\section{Johtopäätökset}

Siemenseoksia suunniteltaessa täytyy ottaa huomioon kasvien ominaisuudet. Kasvilajivalinta täytyy tehdä myös sen mukaan, tarvitaanko tilalla hyvin sulavaa ja valkuaispitoista rehua lypsylehmille ja lihanaudoille vai onko tilalla hiehoja ja emolehmiä, jotka tarvitsevat vähemmän energiaa ja valkuaista.

Kasvuajan edetessä kasvien valkuaispitoisuudet laskevat lukuun ottamatta vihantarehuherneitä. Valkuaispitoisimpia kasveja ovat virnat ja kaikkien palkokasvien valkuaispitoisuudet olivat varsin korkeita. Seoksiin saadaan myös sulavuutta lisäämällä niihin palkokasveja ja erityisesti herneiden sulavuus on korkea. Viljoista ohran ja keväällä kylvetyn syysrukiin sulavuudet ovat kohtuullisen korkeita.

\section{Kirjallisuus}

Adesogan, AT., Salawu, MB. \& Deaville, ER. 2000. The effect of pea to wheat ratio and harvest date on the voluntary feed intake, in vivo digestibility and nitrogen retention of pea-wheat bi-crop silages by sheep. Proceedings of the British Society of Animal Science. 82.

Ahvenjärvi S., Joki-Tokola E., Vanhatalo A., Jaakkola S. \& Huhtanen P. 2006. Effects of replacing grass silage with barley silage in dairy cow diets. Journal of Dairy Science. 89: 1678-1687.

Åman, P. \& Graham H. 1987. Whole-crop peas. I. Changes in botanical and chemical composition and rumen in vitro degradability during maturation. Animal Feed Science and Technology. 17: 15-31.

Anil, L., Park, J. \& Phipps, RH. 2000. Temperate intercropping of cereals for forage: a review of the potential for growth and utilization with particular reference to the UK. Animal Feed Science and Technology. 86: 157-164.

Borreani, G., Peiretti, PG. \& Tabacco, E. 2007. Effect of harvest time on yield and pre-harvest quality of semi-leafless grain peas (Pisum sativum L.) as whole-crop forage. Field Crops Research. 100: 1-9.

Fraser, MD., Fychen, R. \& Jones, R. 2001. The effect of harvest date and inoculation on the yield, fermentation characteristics and feeding value of forage pea and field bean silages. Grass and Forage Science. 56: 218-230.

Huhtanen, P., Nousiainen, J. \& Rinne, M. 2006. Recent developments in forage evaluation with special reference to practical applications. Agricultural and Food Science. 15: 293-323.

Huhtanen, P., Rinne, M. \& Nousiainen, J. 2007. Evaluation of the factors affecting silage intake of dairy cows: a revision of the relative silage dry-matter intake index. Animal. 1: 758-770.

Huhtanen, P., Nousiainen, J.I., Kytölä, K., Khalili, H. \& Rinne, M. 2008. Utilization and partition of dietary nitrogen in dairy cows fed grass silage based diets. Journal of Dairy Science 91: 3589-3599. 
Koivisto, JM., Benjamin, LR., Lane GPF. \& Davies, WP. 2003. Forage potential of semi-leafless grain peas. Grass and Forage Science. 58: 220-223.

Mustafa, AF., Christensen, DA. \& McKinnon, JJ. 2000. Effect of pea, barly, and alfalfa silage on ruminal nutrient degradability and performance of dairy cows. Journal of Dairy Science. 83: 2859-2865.

Mustafa, AF. \& Seguin,P. 2004. Chemical composition and in-vitro digestibility of whole-crop pea-cereal mixture silages grown in South-western Quebec. Journal of Agronomy Crop Science. 190: 416-421.

Nelson, CJ. \& Moser, LE. 1994. Plant factors affecting forage quality. In: Fahey, GC., Collins, M., Mertens, DR., Moser, LE. (Eds.). Forage Quality, Evaluation and utilization. ASA-CSSA-SSSA Publishers, Madison, WI. Pp. 115-154.

Nousiainen, J., Rinne, M., Hellämäki, M., \& Huhtanen, P. 2003. Prediction of the digestibility of the primary growth of grass silages harvested at different stages of maturity from chemical composition and pepsin-cellulase solubility. Animal Feed Science and Technology. 103: 97-111.

Nykänen, A., Jauhiainen, L. \& Rinne, M. 2009. Biomass production and feeding value of whole-crop cereallegume silages. In: eds. Luule Metspalu et al.. Fostering helthy food systems through organic agriculture - focus on Nordic-Baltic region. Agronomy Research 7: 684-690.

Nykänen, A. \& Jauhiainen, L. 2010. Herneillä ja virnoilla typpiomavaraisuutta kokoviljatuotantoon. Maataloustieteen Päivät 2010.

Phipps, RH., Sutton, JD. \& Jones, BA. 1995. Forage mixtures for dairy-cows: The effect on dry-matter intake and milk-production of incorporating either fermented or urea-treated wheat, brewers grains, fodder beet or maize silage into on grass-silage. Animal Science. 61: 491-496.

Pursiainen, P. \& Tuori, M. 2006. Replacing grass silage with pea-barley intercrop silage in the feeding of the dairy cow. Agricultural and Food science. 15: 235-251.

Pursiainen, P. \& Tuori, M. 2008. Effect of ensiling field bean, field pea and common vetch in different proportions with whole-crop wheat using formic acid or an inoculant on fermentation characteristics. Grass and Forage Science. 63: 60-78.

Rinne, M., Huhtanen, P. \& Nousiainen, J. 2008. Säilörehun ja koko rehuannoksen syönti-indeksit auttavat lypsylehmien ruokinnan suunnittelussa. Julkaisussa: Maataloustieteen Päivät 2008 [verkkojulkaisu]. Suomen

Maataloustieteellisen Seuran tiedotteita no 23. Toim. Anneli Hopponen. Saatavilla Internetissä:

http://www.smts.fi/mpol2008/index_tiedostot/Esitelmat/es086.pdf

Rinne, M., Huhtanen, P., \& Nousiainen, J., 2008. Karkearehujen sulavuuden määritys tarkentunut. Julkaisussa: Maataloustieteen Päivät 2008 [verkkojulkaisu]. Suomen Maataloustieteellisen Seuran tiedotteita no 23. Toim. Anneli Hopponen. http://www.smts.fi/mpol2008/index_tiedostot/Posterit/ps024.pdf.

Rondahl, T., Bertilsson, J., Lindgren, E. \& Martinsson, K. 2006. Effects of stage of maturity and conservation strategy on fermentation, feed intake and digestibility of whole-crop pea-oat silage used in dairy production. Acta Agriculturae Scandinavica Section A. 56: 137-147.

Salawu, MB., Adesogan, AT. \& Dewhurst, RJ. 2000. Milk production from dairy cows offered pea-wheat bicrops containing different ratio of peas to wheat and harvested at two maturity stages. Proceedings of the British Society of Animal Science. 150.

Salawu, MB., Adesogan, AT., Weston, CN. \& Williams, SP. 2001. Dry matter yield and nutritive value of pea/wheat bi-crops differing in maturity at harvest, pea to wheat ratio and pea variety. Animal Feed Science and Technology. 94: 77-87.

Salawu, MB., Adesogan, AT., Fraser, MD., Fychan, R. \& Jones, R. 2002. Assessment of the nutritive value of whole crop peas and intercopped pea-wheat bi-crop forages harvested at different maturity stages for ruminants. Animal Feed Science and Technology. 96: 43-53.

SAS 2004. SAS/STAT 9.1 User's Guide. Cary, NC: SAS Institute Inc. 5121p.

Sutton, JD, Abdalla, AL., Phipps, RH., Cammell, SB., Humpries, DJ. 1997. The effect of the replacement of grass silage by increasing proportions of urea-treated whole-crop wheat on food intake and apparent digestibility and milk production by dairy cows. Animal Science. 65 : 343-351.

Thornton, RF \& Minson, DJ. 1973. The relationship between apparent retention time in the rumen, voluntary intake and apparent digestibility of legume and grass diet in sheep. Australian Journal of Agricultural Research. 24: 889-898.

Waghorn, GC., Shelton, ID. \& Thomas, VJ. 1989. Particle breakdown and rumen digestion of fresh ryegrass and Lucerne fed to cows during a restricted feeding period. British Journal of Nutrition. 61: 409-423. 